\title{
Investigating Pedagogical Techniques in Classroom Interactions at a CELTA Training Programme
}

\author{
Md Shidur Rahman ${ }^{1}$ \\ ${ }^{1}$ School of Education, Queen's University Belfast, Belfast, UK \\ Correspondence: Md Shidur Rahman, 69-71 University Street, Queen's University Belfast, Belfast, UK, BT7 \\ 1HL. Tel: 44(0)789-498-7320. E-mail: shidureh@yahoo.co.uk
}

Received: May 6, 2016 Accepted: July 9, 2016 Online Published: July 10, 2016

doi: 10.5539/elt.v9n9p1 URL: http://dx.doi.org/10.5539/elt.v9n9p1

\begin{abstract}
The study investigated the similarities and dissimilarities of using pedagogical techniques in classroom interactions, taken place whilst teaching a known language and an unknown language in a CELTA training classroom context. For this purpose, the classroom interactions in unknown and known languages were analysed according to the qualitative research method. First, the interactions were recorded; and then transcribed them by following Jefferson's transcription conventions. The interactants were one instructor (Female), and twelve trainees: seven females and five males. Usually, the CELTA has a maximum class size of tweleve. The instructor was a native-speaker of English, but the trainees were the mixture of native and non-native speakers. One was from Thailand, one from Indonesia, one from Bangladesh; two from Europe, and the rest were from the UK. Most of the trainees had teaching experience. The results of the study indicated that there exist distinctions, rather than similarities, between pedagogical strategies ued while teaching known and unknown languages. The study also suggested that all the pedagogical techniques do not fit equally with teaching both the languages; some can be used in a wider degree — some can be employed in a lesser degree.
\end{abstract}

Keywords: classroom interaction, discourse, language teaching, pedagogy, teacher talk

\section{Introduction}

Classroom interaction is a multifaceted phenomenon ( $\mathrm{Wu}, 1998)$ as it has some distinctive features such as interaction usually follows IRF (Initiation-Response-Feedback) pattern; and underlines some pedagogical methods such as: negotiating meaning, drilling, elicitation, reformulation, TTT (teacher talking time), STT (student talking time), and so on (Walsh, 2006a). All these methods are regarded as pedagogical techniques-because they entail learning or teaching methodologies (Thornbury, 2006). Besides, Edwards-Groves and Hoare (2012) regarded the classroom interaction as a core practice of teaching and learning. This study aims to compare the pedagogical techniques emerged from classroom interactions in a known language with interactions in an unknown language in a CELTA training classroom context. CELTA, an acronym which stands for Certificate in English Language Teaching to Adults, focuses on learners, teachers and teaching (Wilson, 2015). In this study 'a known language' indicates that students know the language used in a lesson, whereas 'an unknown language' means that students are unfamiliar with the language used for interactions in a lesson. For example, a group of students knows English, and which is the medium of instruction for a particular lesson. Therefore, English is a known language or may be an L1 for them. But when a group of pupils tends to learn quite a new language such as Irish, and so, the Irish would be an unknown language for them; or their Irish proficiency would be zero.

The rationale for choosing the classroom interaction analysis based on CELTA training classroom context lies in knowing firstly that a research gap is discovered because a number of researchers studied interactions in various other classroom contexts such as health science (Woodward-Kron \& Remedios, 2011), corpus study of classroom discourse (Csomay, 2013), the use of L1 and L2 (Temmerman, 2009), elementary school (Kim, 2013), secondary school (Lo \& Macaro, 2012), high school science lessons (Scott, Mortimer, \& Aguiar, 2006), mathematics classrooms (Salam \& Shahrill, 2014), and EFL classrooms (Walsh, 2002; Li \& Walsh, 2011; \& Walsh, 2012). But, a very few studies so far are undertaken focusing on comparing the pedagogical techniques found in known and unknown language classroom interactions in a CELTA training context. Secondly, investigating this research vacuum is significant as the study will offer an insight into how students realise the 
situations of interaction in a language they do not know — even when they are not informed of the name of that language to be taught. Then, this study will also provide a new understanding of what pedagogical techniques are more applicable to the known language teaching and learning; and to the unknown language teaching and learning. Finally, the study will benefit those who with no knowledge or little knowledge about how the classroom interaction works for a new language teaching-as it will also ponder the interaction patterns alongside the pedagogical techniques. Just to recap, the main focus of this study is to compare the pedagogical techniques noticed within the interactions in a new language (Irish) with the techniques noticed within the interactions in a known language (English). So, the study addresses the following research question:

What are the differences and similarities between the pedagogical techniques noticed to be applied within the classroom interactions in known and unknown language?

\section{Research Context}

The context of this study is a CELTA training classroom at Oxford House College London UK. The classroom was of trainees from different countries (UK, Thiland, Indonesia, Bangladesh), and of native and non-native speakers of English. Three compulsory components of CELTA training programme were: a). Input session, tutorials, and tutor's feedback on teaching practice; b). Six hours minimum of observation of qualified and experienced teachers; and c). Six minimum hours of supervised teaching practice (Brandt, 2010). On the input session, the instructor staged an unknown language (Irish) in the class, and attempted to teach it to the trainees - as at every CELTA training program there is often an input session on an entirely unfamiliar language so that the trainees can consider the importance of learning style and teaching techniques (Trinity College London, 2016). Any language for an input session is likely to be selected as an unknown language depending upon which language a group of trainees do not know-and the trainees' unknown language is confirmed when enrolment at the program is ended. With regard to this study, Irish, as an unknown language, was chosen to be used in the input session because the trainees had no prior knowledge about it. Subsequently, the instructor engaged the trainees in another lesson in English, and everybody knew English in that lesson. The content of subsequent lesson was just about preceding lesson: teaching Irish as a new language.

\section{Review of Literature}

\subsection{Defining Classroom Interaction}

Interaction is a two-way process (Malamah-Thomas, 1987; Dagarin, 2004) which takes place between participants or interactants. In terms of classroom context, interaction usually occurs between teacher and student participants, but also between students and students (Tsui, 2001; Lo \& Macaro, 2012; Kim, 2013; Salam \& Shahrill, 2014; Scrivener, 2011). However, Malamah-Thomas (1987) claimed that textbook writers can also become the participants as they transmit messages via the textbooks. Therefore, sometimes, teachers, students and textbook writers are deemed as participants in classroom interaction. Nonetheless, this is not likely to be the case in all classroom situations because textbooks may not be used in each classroom setting such as the action research study, without using textbooks in the class, conducted by Cristo (n.d.) proves that learners acquire English without the help of textbooks. Besides, textbook writers are not active or direct participants because students cannot talk to the textbooks. Therefore, teachers and students can usually be recognised as important classroom interaction participants.

The classroom interactions can contribute to facilitating as well as to obstructing learning opportunities (Walsh, 2002). Interaction in a classroom centres on learning (Walsh, 2012) - it opens the opportunities of learning. This claim seems reasonable because students learn from the teacher-talk, such as Wasik and Hindman's (2014) study shows that the teacher-talk fosters children's vocabulary learning. The children also learn from their own talk when engaging in a pair or group work (Otienoh, 2015). So the classroom interaction benefits students for learning. However, some claimed that classroom interaction sometimes can hinder learning - such as an excessive teacher talk and intervention may decline learning potential (Walsh, 2002). That is to say, less space is allocated for students' voice when teachers talk enormously. As in the words of Edwards and Westgate (1992), the teachers take turns, distribute turns to others, select topic, disrupt and reallocate turns, and comment on students' talk. This disproportionate distribution of communicative rights between teachers and pupils is obvious in the classroom interaction (Thornborrow, 2002). Withstanding these drawbacks, classroom interaction is beneficial as Krashen's (2013) comprehensible input hypothesis indicates that interactive exposures foster learners' language acquisition. The next section concentrates on classroom interaction structure.

\subsection{Patterns of Classroom Interaction}

The first, basic, typical, and most influential classroom interaction pattern is IRF (Initiation-Response-Feedback) 
model which was coined by Sinclair and Coulthard (1975) in the1970s (McCarthy, 2001; Hardman, 2008). An example of this pattern is as follows:

Teacher: What is this, John? (Initiation)

Student: Pen (Response)

Teacher: Yes (Feedback)

Lemke (1990) termed this pattern (IRF) as triadic dialogue, and Mehan (1979) called it as IRE in which E stands for evaluation.

Some researchers argued that the IRF pattern has some benefits and shortcomings. Seedhouse (1996), for example, argued that IRF cycle and display questions - as interactional features - are suitable for achieving the core goal of classroom interaction: learning or education. Likewise, Gibson (2014) pointed out that the IRF framework attempts to determine the pedagogic relationships between participants in education contexts. Learners, such as, take initiatives after teacher's feedback, they use language to configure and reconfigure the patterns of participation and to create learning opportunities (Waring, 2011).

Unlike the above benefits, some limitations are highlighted by different researchers. Walsh (2006b), for instance, claimed that Sinclair and Coulthard (1975) established this model relying upon the study of traditional primary classrooms, and L1 (first language) classroom interaction (Seedhouse, 2004) which are inadequate to interpret the environments of L2 classroom (Cancino, 2015). Moreover, Stubbs (1983) criticised that knowledge is unequally distributed between teachers and pupils in IRF model - teachers usually ask the questions to which they know the answers. In order for it to be effective in a classroom interaction study, despite these shortcomings, IRF pattern is still remarkably appropriate (Li \& Walsh, 2011). Johnson (1995) suggested that a large amount of L2 classroom interactions is held in an IRF/IRE pattern.

\subsection{Pedagogical Techniques in Classroom Interaction}

Given the definition and patterns of classroom interaction, a particular attention needs to pay to the pedagogical techniques noticed in classroom interaction as firstly; there is an intimate link between pedagogy and interaction which is the unique feature of the L2 classroom. Seedhouse (2004, P. 187), for example, stated that, "There is a reflexive relationship between pedagogy and interaction." It means, in terms of L2 learning in particular, learner utterances are potentially evaluated by the teacher. So, the third turn of the classroom interaction renders learning. Ellis (2012) also denoted that the classroom interaction contributes to L2 learning as well as acquisition. Beyond this, the pedagogical techniques are the main focus of this study. Some of the techniques, therefore, such as drilling, elicitation, scaffolding, negotiation of meaning, student-talking time (STT) and teacher-talking time (TTT) are discussed below. All these pedagogical techniques, however, are not likely to be equally applicable to teaching the students at all language proficiency levels - for example, the drilling or repetition teaching method may be more effective to the beginner level of students than the advanced level's.

\subsubsection{Drilling or Repetition and Elicitation Technique}

Drilling is a method of language teaching. Thornbury (2006, p. 71) stated, "A drill is repetitive oral practice of a language item, whether a sound, a word, a phrase or a sentence structure." Thornbury's (2006) point is that in drilling method the teacher prompts the language items and the student responds them, and this process develops the automaticity of the items. It seems that repetition is the key to drilling method. Now arguments are on which proficiency level of learners the repetition method is best fit with. In this respect, Harmer $(1998,2001)$ argued that the use of repetition seems more suitable for the beginner level students; and less for the students at higher levels. He also opined that using the repetition technique at advanced level seems strange and patronising. Alternatively, it is easy to set up a discussion task at an advanced level.

However, Tice (2004) seems not to agree with Harmer's $(1998,2001)$ claim when she says, "At all levels we should drill vocabulary or chunks of language that cause pronunciation problems." The essence of this argument is that alongside with the lower level students, the higher levels, too, could encounter problems with some aspects of pronunciation such as stress, phrase level intonation, and so on. Phrases, for example - "If I'd know you were coming, I'd have stayed at home", are hard to express. So these phrases should be drilled even when the students are at higher level of their proficiency.

Harmer's position can be supported that drilling technique is rather applicable to the lower proficiency level of students than to the higher level of students. Other researchers also have agreed with Harmer's idea. Swanto and Din (2014), for example, found that drilling technique helps the low proficiency ESL learners to improve their writing skills. Roberts (2012) said that, "Especially at lower levels, it is quite natural to rehearse (at least 
mentally) before tackling a speaking situation." In summary, drilling technique is used relatively more at lower levels, but sometimes it can even be highly used at higher levels if situations dictate.

Drilling often follows on from the process known as eliciting (Kelly, 2000). The use of eliciting strategy during teaching is another pedagogical strategy that prompts the learner to self-correct (Brown, 2007). This is, therefore, a type of teacher's corrective feedback and learner repair in the real classroom (Lee, 2013). The teachers use this instrument for various purposes such as eliciting chunks and organised speech (Brown \& Yule, 1983), long answers and personal information from students (Doff, 1988). However, in the discussions of elicitation strategy as one of the pedagogical techniques, a controversial issue has come across which is whether the elicitation technique is more suitable to use in a lower level or an advanced level of ESL classes. Some argued that elicitation is the best applicable to the beginner-level students. From this perspective, the study by Panova and Lyster (2002) demonstrated that the elicitation, albeit it was applied rather little by the teachers, was more successful in beginner-level classes because elicitation led to the highest rate of learner repair. In the similar vein, Han and Jung (2007 cited in Lee, 2013) uncovered that elicitation often used by the teachers resulted in a significant learner repair at lower level classes. On the contrary, others argued that elicitation is less effective in advanced ESL classes. Lee's (2013) study itself, for example, showed that the elicitation resulted in lower rate of learner repair in advanced-level classes; rather, the use of recasts resulted in the highest rate of update. In sum, then, the argument is whether the elicitation method is highly applicable to the lower level ESL classes or advanced level ESL classes.

I am of two minds about the issue of more or less use of elicitation method as per the learner proficiency level. On the one hand, it may be accurate to argue that elicitation serves as correcting students' error at the initial stage of learning. On the other hand, it is hard to ensure if the elicitation technique is utilised at a considerable rate with the advanced level of students.

\subsubsection{Scaffolding Teaching Strategy}

Like drilling, scaffolding is also a popular strategy which has become a topic of inquiry especially in L2 settings for decades (Kayi-Aydar, 2013). Gibbons (2006) termed scaffolding as assistance in learning - in other words, scaffolding means support for learning (Engin, 2012). Examples of support for learning in a language class are showing and telling, tapping into prior knowledge, using visual aids, allowing time for learners to talk, and so on. In a classroom context, it is the process of interaction between two or more people as they carry out a classroom activity and where one person (e.g., the teacher or another learner) has more advanced knowledge than the other (learner) (Swain, Kinnear, \& Steinman, 2010 cited in Rodgers, 2014). There seems that scaffolding may be more essential for the students at lower knowledge. Hyland (2006) also claimed that scaffolding moves the students from an existing performance level to an independent performance level. These words of Hyland (2006) prove that a student at lower-level of understanding needs more help in order to reach the upper-level. The discussion so far indicates an expert (a teacher or parent)-novice (a student or child) relationship. In order to scaffold, a more knowledgeable person (expert) interacts with a less knowledgeable person (novice).

However, some researchers' work (such as Gibbons, 2002; Mercer, 1995; \& Rogoff, 1995 cited in Walqui, 2006) demonstrated the idea that scaffolding is not concerned only with the expert-novice relationship, but also with the relationship of equal knowledge. For example, students working in groups produce a result which has not been possible to produce on their own. In this case, engaging in a group work, regardless of their levels, students share their knowledge; help reciprocally; and produce the result. So, it may not always be the case that the only less knowledgeable pupils need scaffolding rather than the expert ones. The advanced students, now and then, may also need support to a greater extent.

Although I concede that the students who are novice for learning a foreign language may require additional supports, I still insist that scaffolding is required for all learners (regardless of whether the students are novice or not) and for all subject areas-the same as almost every building needs scaffolding during the construction or renovation (Holton \& Clarke, 2006).

\subsubsection{Negotiation of Meaning}

Another pedagogical technique, which is seen to be developed from classroom interaction, is the negotiation of meaning. According to Ellis (2008, p. 973), "Communication involving L2 learners often leads to problems in understanding and communication breakdown. Frequently, one or more participants - the learner or the interlocutor - attempts to remedy this breakdown by engaging in interactional works to secure mutual understandings. This work is often called 'negotiation of meaning'." It means that the interaction is modified, and which is accepted by the involved participants. The modification strategies, for example, are confirmation check, clarification request, and comprehension check (Mayo \& Ibarrola, 2015). 
However, there is a need to investigate whether the negotiation strategy suits only the adult or high proficient learners or all categories of learners. Ellis (2001) presented that meaning negotiation helps learners secure language acquisition even if they have no grammatical knowledge. That is to say, meaning negotiation occurs in learners, regardless of their linguistic proficiency.

But other researchers have argued that the negotiation strategy best fits in with the learners in higher proficiency level (advanced level). One of this view's proponents, Pica (1994 cited in Lee, 2001) argued that, due to their insufficient linguistic knowledge, negotiation is not more likely to occur at the learners' early stages of language development. Lee (2001) also found that negotiation depends on the learner's language development level. Moreover, Ellis, Basturkmen and Loewen (2001) stressed on the adult learners in terms of using negotiation strategy than the young learners. So the learner's lower language proficiency and age may affect the meaning negotiation.

I would argue that a higher level of negotiation of meaning is found to be occurred in the lower proficiency learners rather than in the higher proficiency ones. This is because that the communication breakdown or understanding problems may occur in lower proficiency learners to a greater extent than in those of higher proficiency level. For example, the study by Oliver (2002) showed that a considerable amount of negotiation for meaning was created by the low proficiency learner pairs.

\subsubsection{Teacher-Talking Time (TTT) and Student-Talking Time (STT)}

Lastly, the amount of TTT and STT relies upon different viewpoints such as pedagogical principles and the particular goals of syllabus (Nunan, 1991; Chaudron, 1988). From these perspectives, for example, a learner-centred approach emphasises more on student-talk in the L2 classroom context (Hitotuzi, 2005). Another significant aspect is that the degree of TTT and STT depends on the learner's proficiency levels such as beginner, elementary, pre-intermediate, intermediate, upper-intermediate, and advanced level. A lot of arguments, surrounding the amount of TTT and STT depending on learner's proficiency levels, exist in the literature. Hitotuzi (2005) suggested that, in terms of elementary classroom, a balance is to be established between teacher-centredness and student-centredness though more learner-centredness is needed for intermediate-level class. This means that the quantity of STT should be larger in the intermediate level. However, the study of Cullen (1998) showed that a classroom interaction at an Egyptian lower secondary school was heavily teacher-led, and the teacher's excessive talk in the class was supportive for learning. In other words, the higher rate of TTT at lower proficiency level classes is rather effective.

Cullen's study is important as TTT is likely to be adequately useful for the lower proficiency learners. Besides, Krashen's (1981) comprehensible input hypothesis shows that the relevant input develops learner's low proficiency level $\mathrm{i}$ to the $\mathrm{i}+1$. The study result of Ioup (1984), for example, demonstrated that the lower-intermediate class improved significantly with the help of inputs rather than the higher-intermediate level did. So, the extensive teacher talk can assist the lower proficiency level learners more than the higher ones.

In order to sum up the literature review section, it is apparent that the existing literature has highlighted the key theme of this study - classroom interaction and pedagogical techniques. The literature also suggests that all pedagogical techniques do not equally work with all proficiency levels of learners. The teaching items, lesson plan, syllabus, learner needs, and so on also dictate which techniques can be appropriate to which level of learners. Furthermore, setting up these pedagogical techniques depends upon the learner variables: age, adult, child, educational background (Celce-Murcia, 1991); and besides, individuals learn different ways (Hartnett, 1985 cited in Celce-Murcia, 1991).

\section{Method}

\subsection{Participants}

The participants for this study were an instructor (Female), and 12 trainees: seven females and five males. The instructor was a native-speaker of English, but the trainees were the mixture of native and non-native speakers. One was from Thailand, one from Indonesia, another one from Bangladesh; two from Europe, and rest of the trainees were from the UK. Most of the trainees had teaching experience.

\subsection{Participant Selection Procedure}

The study took place in January 2012 at Oxford House College London, UK where the trainees had enrolled at a CELTA training course. Generally, the CELTA training course has a maximum class size of 12 (British Council, 2016). The college, therefore, selected 12 trainees for the January session. This may seem to be a smaller sample size that raises the issue of generalizability to the whole population of the research (Harry \& Lipsky, 2014; Thomson, 2011). But the generalisability seems not to be a problem as Darlington and Scott $(2002$, p. 18) 
pointed out that, "If one considers the unit of attention as the phenomenon under investigation, rather than the number of individuals, then the sample is often much larger than first appears." Similarly, in this study the number of interactions would have been larger than the individuals involved. So, the sample size of 12 is probabaly not inappropriate for this kind of qualitative nature of study.

\subsection{Data Collection Strategies}

A. The consent of the interactants was taken prior to recording the interactions - the consent has also been taken again for using the record for this research. An email was sent to the instructor-participant by seeking her permission on this regard.

B. The audio-recording of interactions between instructor and trainees was undertaken using Dictaphone in January 2012. Each of the lessons was observed too. The recording was 01:18:41 in total. The entire recording was separated into two parts. The first part of 00:00:00 to 00:51:35 was of interactions in unknown language (Irish), but this study used only $03 \mathrm{~min} 40 \mathrm{sec}$ from the beginning of recording for analysis. While the second part of 00:51:36 to 01:18:41 was of interactions in known language (English), but this study used only from 00:57:25 to $01: 00: 04$ or $02 \mathrm{~min} 39 \mathrm{sec}$ of recording for analysis.

C. The transcription of recording was divided into excerpt 1 and 2, and then they were transcribed by following the transcription conventions of Jefferson (2004) (See Appendix A). The excerpt 1 was about classroom interaction in unknown language (Irish), and the excerpt 2 was regarding classroom interaction in known language (English) (See Appendix B).

D. It is also mentioned that the unknown language (Irish) in excerpt 1 was translated into English for the reader's understanding.

\subsection{Procedure and Data Analysis}

In order to analyse the transcribed data, qualitative method was employed for this study. This method was chosen for two reasons. The first, the collected data were interpreted in words, not in numbers. As is also stated by Bryman (2012, p. 380) that, "Qualitative research is a research strategy that usually emphasises words rather than in the collection and analysis of data." The second, qualitative research is concerned with multiple perspectives (Rahman, 2015). Same as in this study, the focus was on multiple pedagogical techniques. Then differences and similarities between pedagogical techniques noticed to be used in classroom interactions were elicited. In a word, data analysis was in words, not in numbers.

\section{Results}

As outlined earlier, this paper intended to compare the pedagogical techniques in classroom interactions of known and unknown languages. So this part of the paper wishes to present the distinctions and similarities of pedagogical techniques noticed to be applied between interactions of two different lessons. But, prior to embarking upon analysing the pedagogical techniques, an attention is necessitated to pay to the interaction patterns of these two distinct lessons.

\subsection{Differences and Similarities: Interaction Patterns}

The collected data in excerpt 1 clarify that the interactions in new language chiefly followed initiation-response pattern (In lines 4-8, 16-21, 39-50, 61-71) and the IRPRPRE (Initiation-Response-Prompt-Respond-Prompt-Response-Evaluation) pattern was found too (In lines 9-15, 27-32). The excerpt 1 also shows that a large number of interactions, though not all, occurred between the instructor and the whole class (In lines 3, 12, 25, 30, 32, 34, 37, 40, 42, 44, 46, 48, 50, 60, 66, 70, and 74). For instance, in lines 28-32, the whole class repeated the expression: An-mhaith (Very good) with the instructor. Moreover, the excerpt 1 reveals that the instructor held the turns for a short time; no prolonged turns were obvious to be taken by the instructor.

On the other hand, in excerpt 2 the classroom interaction pattern in known language (English) is particularly of IRF pattern in which opening moves conducted by the instructor with referential questions (The instructor does not know the answer) (In lines 1, 10, 12, 19, 30-34, 47, 51, 58). Then, the instructor allocated the turns to the individual trainee. Consequently, the interactions took place between the instructor and the individual trainee rather than between the instructor and the whole class. An example of this is that the instructor nominated the trainee by name such as Tina, Sonny; and continued interactions with them (In lines 1-18, 51-57). Additionally, the instructor prolonged the turns (In lines 15-18, 30-34, and 36-44). Along with the differences, some similarities do exist. One of the similarities is that the IRF interaction pattern is noticed in excerpt 1 (Lines 2-4) as well as in excerpt 2 (Lines 1-3). 


\subsection{Differences and Similarities: Pedagogical Techniques}

Having presented the comparison relating to the interaction patterns, this segment turns attention to the comparison of pedagogical techniques, the central focus for this paper.

\subsubsection{Differences}

The interactions in excerpt 1 differ from the interactions in excerpt 2 with the respect to some pedagogical techniques. Firstly, the collected data in excerpt 1 encapsulates that the interaction in unknown language was full of repetitions. The words such as-Dia dhuit (Hello), An-mhaith (very good), go maith (well), Go dona (Bad) were echoed widely by the instructor (In lines 3-10, 16-21, 25-32, 39-46, 47-50). That is to say, the instructor employed repetition drilling technique for teaching the new language. While the interaction at the lesson of known language in excerpt 2 encompasses that the instructor utilised no drilling method at all; instead, she used question-answer elicitation technique in which display and referential questions were made. For example,

Excerpt 2: Referential question (The instructor had no idea of the answer)

$1 \quad$ I: Tina (.) do you have any experience?

2 Tina: No

The instructor did not know whether Tina had experience or not.

Excerpt 2: Display Question (The instructor knew the answer)

58 I: Do you know how many pupils you will be teaching? Did Boby ever

$59 \quad$ mention?

60 T: Twelve

61 I: $\quad$ Yea (.) maximum twelve.

But in this question, the instructor already knew that the trainee-participants were supposed to teach a maximum of twelve pupils in one class.

Secondly, the interactions in excerpt 1 demonstrate that the instructor wrote some words (e.g. Dia dhuit, An-mhaith, Ní hea, and Is ea) of Irish language on the board which supported the learners for acquiring pronunciation (In lines 10, 15, 60,69). This sort of support is regarded as scaffolding. Whereas, scaffolding teaching technique of any sort is hardly noticed in excerpt 2.

Thirdly, in terms of lesson in new language at excerpt 1, the instructor is seen to negotiate meaning with the trainee participants. At the very beginning of the lesson, the trainees were not able to understand the meaning of Dia dhuit. As a result of this, the instructor would get the trainees repeated the word (Dia dhuit) quite a few times in order that they could understand the meaning (In lines 2-10). Besides, a communication breakdown happened between the instructor and Mohammed, one of the trainees (In lines 55-58). Mohammed could not understand the meaning of Conas atá tú? But when the instructor modified the communication by repeating the phrases (Conas atá tú?; Conas atá tú?) (Line 57), it was clear to Mohammed for what to reply (In line 58). By contrast, at the lesson of known language in excerpt 2 , the instructor is not found to utilise the meaning negotiation strategy of teaching.

Then, the excerpt 2 reflects the higher rate of TTT than the excerpt 1. It is apparent in excerpt 2 that the instructor sometimes lengthened the talk in her turns rather than in trainees' turns (In lines 15-18, 30-34, and 36-44). This signifies that the instructor talked longer than the trainees. Conversely, the instructor, in excerpt 1 , did not hold the turns longer-rather, she involved the trainees with a lot of repetitions as mentioned previously. So, the TTT is noticed at lesson in known language more than at lesson in unknown language.

Together with the above, the differences related to other aspects emerged from the extracted data. The excerpt 1 , for instance, exposes that the participants used mostly words and phrases for interactions. No sentences, such as, are employed in lines 1-21 and 24-54. But, in excerpt 2, the participants particularly employed sentences for interactions. Then, the interactions in excerpt 1 show that the trainees had zero information about the lesson such as at the start of the lesson the trainees greeted in English: Hello (.) Hello (1), but in return the instructor responded in Irish: Dia dhuit (Hello) (.) Dia: dhuit (Hello) (2). It seems that the trainees became surprised to hear the sound, Dia dhuit. While the interactions in excerpt 2 indicate that the subject of talk, which was about the teaching strategies of a new language such as working in groups and pairs (In lines 10-13) and a teacher-centred or a student-centred approach (In lines 34-35), was familiar to the trainees. So, the lesson in a new language is more controlled by the instructor, and it seems that the learners are being spoon-fed instead of being allowed to demonstrate their opinions; but the lesson in known language is less controlled by the instructor as the trainees 
displayed their thoughts and opinions, albeit the instructor talked more than the trainees.

\subsubsection{Similarities}

However, some analogies, yet not like many differences above, are observed in between the interactions of both excerpts concerning pedagogical techniques. First of all, the classroom interactions in excerpt 1 and 2 are similar with respect to using elicitation method of teaching. For example, the instructor elicited the second part of Dia gwitch in excerpt 1 :

$$
\begin{array}{lll}
13 & \text { I: } & \text { Di:a...? } \\
14 & \text { T: } & \text { gwitch (1.5) }
\end{array}
$$

Likewise, as in excerpt 2, the instructor endeavoured to elicit Tina's opinions and ideas of working in pairs and groups through questioning such as:

9 I: Right, Ok.

10 Do you like working like in pairs, groups, etc.?

11 Tina: Yea

Then, similarity is also uncovered as regards to a good relationship between the participants. The friendly environment prevailed in the both lessons, as is evident that the trainee-participants had laughing few times during interactions (In lines 17 and 36, excerpt 1; and lines 25, 26, and 45, excerpt 2). All this suggests that there are some, especially, pedagogical variations as well as alignments between interactions in new language and known language. The following section will discuss the indications and implications of these distinctions and analogies.

\section{Discussion}

The study has underlined some important points associated with the interaction patterns. Researchers claimed that the IRF pattern is a dominant and appropriate classroom interaction (e.g. Johnson, 1995; Gibson, 2014; \& Li \& Walsh, 2011). But, this study shows that the IRF pattern seems not always to be hegemonic in classroom interaction as the optimum use of IR (Initiation-Response) and IRPRPRE pattern is recognised in excerpt 1 though it is predominantly used in excerpt 2. Therefore, Li and Walsh (2011) and Gibson (2014) are perhaps not entirely right to claim that the IRF is remarkably appropriate for classroom interaction. A new understanding can also be made from this study that the IR and IRPRPRE patterns (Scott, Mortimer \& Aguiar, 2006) are more appropriate for classroom interaction than the IRF, especially when teaching a new language or lower proficiency L2 learners. Lastly, the nature of turn-taking in both the lessons indicates that the instructor is dominant in classroom interaction as a result of nominating trainees to take the turn, of deciding the turn, and of topic movement. So, Edwards and Westgate (1992), Thornborrow (2002) and Walsh (2006a) are right to claim that the teacher controls the classroom interaction.

Then, as far as the analysis of pedagogical techniques is concerned, at one extreme, some pedagogical features work rather well with the lower proficiency level of learners. At the other extreme, the same startegies may not suit the higher proficiency level of learners to a similar extent or not at all. The study, for instance, found that the drilling - as a means of teaching the new language - denotes that it is rather appropriate for beginner or elementary level of language learners. It is true as in literature review, most of the researchers such as Harmer (1998, 2001), Roberts (2012) and Swanto and Din (2014) also subscribed to this study finding.

Afterwards, the study unearthed that the instructor used elicitation strategy at both the lessons (in known and unknown language). But many (e.g. Panova \& Lyster, 2002; Han \& Jung, 2007 cited in Lee, 2013) argued that the elicitation is mainly useful to apply at teaching the lower level of learners. No literature in this study is found on the use of elicitation to a larger extent related to teaching the higher proficiency level of learner.

Along with the above, the study also indicates that the scaffolding and negotiation of meaning strategies are essentially more applicable to the lower proficiency students or to teaching an unknown language than to teaching a known language or to the advanced learners of that language. With regard to scaffolding, the study findings seem not to be aligned with the literature because most of the researchers claimed that learners of any proficiency level may need support during the lesson (Holton \& Clarke, 2006). However, majority of scholars agreed with the study finding that the negotiation of meaning can immensely be used for teaching the students of lower proficiency level (Oliver, 2002; Ellis, 2001). This claim is also sensible to me because communication breakdown may happen exceedingly while teaching elementary level of learners of a language.

In addition, the findings suggest that it is worthwhile to maximise TTT at advanced level classes. Nonetheless, 
the literature supported the high amount of TTT for lower proficiency level of learners as it promotes their language acquisition effectively through comprehensible inputs (Cullen, 1998; Ioup, 1984; Krashen, 1981).

It is interesting to note that some other peripheral issues are found along with the central focus of this study: pedagogical techniques. Among these, using word and phrase level of language for teaching Irish designates that the trainee-learners of Irish were encouraged to memorise the expressions with drillings (e.g. Kartikasari, Arifin, \& Salam, 2015). This means that learners' Irish language proficiency was at a starting level. So, the teacher's language use relies upon the learner's proficiency level of that language. Another noteworthy indication is that letting the learners know about the lesson in advance is important; otherwise they might be confused about the aim and necessity of the lesson. As in this study, the instructor gave no clue for what the lesson would be about, and consequently the trainee-learners seemed to be saying nothing just after hearing the expression Dia dhuit.

So, the classroom interactions in this study lead to stress on that the teaching tactics are not employed at a similar degree for teaching all proficiency level of learners. As has already been noted from this study that drilling, negotiation of meaning and scaffolding strategies are used in maximum at teaching a new or an unknown language (Irish); while, elicitation technique and more TTT are seen to be used maximally at the lesson in known (English) language. Therefore, it seems that teaching strategy is set up as per the needs of learners and their levels of learning.

\section{Conclusion}

The study aim was particularly to investigate the comparisons of pedagogical techniques emerged in between the classroom interactions held in unknown and known language lessons. To achieve this aim, the study explored the differences and similarities of a CELTA instructor's pedagogical techniques used in two distinct classroom interactions. Now, it is reasonable to claim that the study has projected the likeness and unlikeness of using pedagogical techniques noticed at the interactions of both lessons. For example, the instructor has managed the Irish language classroom using mainly drilling method; but no employment of this method is seen in the classroom interactions in English. However, other pedagogical features such as elicitation, teacher talk are noted to be presented by the instructor at the interactions occurred in known language. Some other incidental issues about teaching and learning appeared through these interactions-for instance, teacher-student unequal power sharing, learner's linguistic level, teacher's language use, and notifying learners about the lesson to be taken place. Such accounts provide a greater understanding of what pedagogical strategies a teacher should apply for teaching a new language and of what strategies a teacher can use for teaching a subject in known language or which techniques should be of a maximum in use and which of a minimum. Hence, the study benefits the teacher trainers, teachers, and those who are planning to start a CELTA training course. The study also contributes to filling the gap in the current literature. Unlike these benefits, the study has some shortcomings. One of these limitations is that it has incorporated the pedagogical techniques sparingly-such as, contextual pedagogical issues for example: classroom environment, learning opportunities, teacher-student relationship are left out. Additionally, the proficiency level is not clearly defined in the literature. So, a large scale of further research is required to be conducted in the future.

\section{Acknowledgments}

A big thank you to Dr Aisling O’ Boyle (Lecturer, School of Education, Queens University Belfast, UK) for her useful instructions and feedback.

\section{References}

Brandt, C. (2010). Competition and collaboration in initial teacher education in TESOL: A case of a classic double bind. The Asian EFL Journal Quarterly Special Issue on English Language Teacher Education and Development September, 12(3), 8-39.

British Council. (2016). CELTA. Retrieved from http://www.britishcouncil.org.eg/en/teach/teacher-training/celta

Brown, H. D. (2007). Principles of language learning and teaching (5th ed.). New York: Pearson Education.

Brown, G.., \& Yule, G. (1983). Teaching the spoken language. Cambridge: Cambridge University Press.

Bryman, A. (2012). Social resaerch methods. New York: Oxford University Press.

Cancino, M. (2015). Assessing learning opportunities in EFL classroom interaction: What can conversation analysis tell us? RELC Journal, 46(2), 115-129. http://dx.doi.org/10.1177/0033688214568109

Celce-Murcia, M. (1991). Grammar pedagogy in second and foreign language teaching. TESOL quarterly, 25(3), 459-480. http://dx.doi.org/10.2307/3586980 
Chaudron, C. (1988). Second language classrooms: Research on teaching and learning. Cambridge: Cambridge University Press. http://dx.doi.org/10.1017/CBO9781139524469

Cristo, M.G.G. (n.d.). Learning and teaching English without a textbook: An action research study. Retrieved from http://www.eslteachersboard.com/cgi-bin/articles/index.pl?page=1;read=1144

Csomay, E. (2013). Lexical bundles in discourse structure: A corpus-based study of classroom discourse. Applied Linguistics, 34(3), 369-388. http://dx.doi.org/10.1093/applin/ams045

Cullen, R. (1998). Teacher talk and the classroom context. ELT Journal, 52(3), 179-187. http://dx.doi.org/10.1093/elt/52.3.179

Dagarin, M. (2005). Classroom interaction and communication strategies in learning English as a foreign language. ELOPE: English Language Overseas Perspectives and Enquiries, 1(1-2), 127-139. http://dx.doi.org/10.4312/elope.1.1-2.127-139

Darlington, Y., \& Scott, D. (2003). Qualitative research in practice: Stories from the field. Social Work Education: The International Journal, 22(1), 115-118.

Doff, A. (1988). Teach English Trainer's Handbook: A Training Course for Teachers (Vol. 1). Cambridge university press.

Edwards, A. D., \& Westgate, D. P. G.. (1992). Investigating classroom talk (2nd ed.). London: Falmer Press.

Edwards-Groves, C. J., \& Hoare, R. L. (2012). "Talking to Learn": Focussing teacher education on dialogue as a core practice for teaching and learning. Australian Journal of Teacher Education, 37(8), 82-100. http://dx.doi.org/10.14221/ajte.2012v37n8.8

Ellis, R. (2001). Introduction: Investigating form - focused instruction. Language learning, 51(s1), 1-46. http://dx.doi.org/10.1111/j.1467-1770.2001.tb00013.x

Ellis, R. (2008). The study of second language acquisition (2nd ed.). Oxford: Oxford University Press.

Ellis, R. (2012). Language teaching research and language pedagogy. West Sussex: John Wiley \& Sons. http://dx.doi.org/10.1002/9781118271643

Engin, M. (2012). Trainer talk: levels of intervention. ELT journal, 67(1), 11-19. http://dx.doi.org/10.1093/elt/ccs048

Ellis, R., Basturkmen, H., \& Loewen, S. (2001). Learner uptake in communicative ESL lessons. Language learning, 51(2), 281-318. http://dx.doi.org/10.1111/1467-9922.00156

Gibson, W. J. (2014). Sequential order in multimodal discourse: Talk and text in online educational interaction. Discourse \& Communication, 8(1), 63-83. http://dx.doi.org/10.1177/1750481313503222

Gibbons, P. (2006). Bridging discourses in the ESL classroom. London: Continuum.

Hardman, F. (2008). Teachers' use of feedback in whole-class and group-based talk. In N. Mercer, \& S. Hodgkinson (Eds.), Exploring Talk in School (pp. 131-150). London: SAGE. http://dx.doi.org/10.4135/9781446279526.n8

Harmer, J. (1998). How to Teach English. Harlow: Longman.

Harmer, J. (2001). The Practice of English Language Teaching (3rd ed.). Harlow: Longman.

Harry, B., \& Lipsky, M. (2014). Qualitative research on special education teacher preparation. In McCray, M. T. Brownell, \& B. Lignugaris/Kraft (Eds.), Handbook of research on special education teacher preparation (pp. 445-460). New York and London: Routledge.

Hitotuzi, N. (2005). Teacher talking time in the EFL classroom. Profile Issues in Teachers Professional Development, 6, 97-106.

Holton, D., \& Clarke, D. (2006). Scaffolding and metacognition. International Journal of Mathematical Education in Science and Technology, 37(2), 127-143. http://dx.doi.org/10.1080/00207390500285818

Hyland, K. (2006). English for academic purposes: An advanced resource book. London: Routledge. http://dx.doi.org/10.1016/j.jeap.2005.11.004

Ioup, G. (1984). Two readers comment on Stephen Krashen's Input Hypothesis: testing the relationsbip of formal instruction to the Input Hypothesis. TESOL quarterly, 18(2), 345-350. http://dx.doi.org/10.2307/3586703

Jeferson, G. (2004). Glossary of transcript symbols with an introduction. In G. H. Lerner (Ed.), Conversation 
Analysis: Studies from the First Generation. Amsterdam, the Netherland: John Benjamins. http://dx.doi.org/10.1075/pbns.125.02jef

Johnson, K. (1995). Understanding communication in second language classrooms. Cambridge: Cambridge University Press.

Kartikasari, E., Arifin, Z., \& Salam, U. (2015). Improving students' speaking ability through repetition drill. Jurnal Pendidikan dan Pembelajaran, 4(1).

Kayi-Aydar, H. (2013). Scaffolding language learning in an academic ESL classroom. ELT journal, 67(3), 324-335. http://dx.doi.org/10.1093/elt/cct016

Kelly, G. (2000). How to teach pronunciation. Harlow: Pearson Education Limited.

Kim, S. (2013). Comparison of task-based and storytelling-based English classroom interaction in Korean elementary schools. English Teaching, 68(3).

Kresan, S. (1981). SecondlLanguage acquisition and second language learning. Oxford: Pergamon Press.

Krashen, S. (2013). Second language acquisition: Theory, applications, and some conjectures. Cambridge: Cambridge University Press.

Lemke, J. L. (1990). Talking science: Language, learning, and values. Norwood: Ablex Publishing Corporation.

Lee, L. (2001). Online interaction: Negotiation of meaning and strategies used among learners of Spanish. ReCALL, 13(02), 232-244. http://dx.doi.org/10.1017/S0958344001000829a

Lee, E. J. E. (2013). Corrective feedback preferences and learner repair among advanced ESL students. System, 41(2), 217-230. http://dx.doi.org/10.1016/j.system.2013.01.022

Li, L., \& Walsh, S. (2011). 'Seeing is believing': looking at EFL teachers' beliefs through classroom interaction. Classroom discourse, 2(1), 39-57. http://dx.doi.org/10.1080/19463014.2011.562657

Lo, Y. Y., \& Macaro, E. (2012). The medium of instruction and classroom interaction: evidence from Hong Kong secondary schools. International Journal of Bilingual Education and Bilingualism, 15(1), 29-52. http://dx.doi.org/10.1080/13670050.2011.588307

Malamah-Thomas, A. (1987). Classroom interaction. Oxford: Oxford University.

Mayo, M. D. P. G., \& Ibarrola, A. L. (2015). Do children negotiate for meaning in task-based interaction? Evidence from CLIL and EFL settings. System, 54, 40-54. http://dx.doi.org/10.1016/j.system.2014.12.001

McCarthy, M. (2001) 'Discourse'. In R. Carter, \& D. Nunan (Eds.), The Cambridge Guide to Teaching English to Speakers Of Other Language (pp. 120-125). Cambridge: Cambridge University Press. http://dx.doi.org/10.1017/CBO9780511667206.008

Mehan, H. (1979). Learning lessons: Social organization in the classroom. Cambridge, MA: Havard University Press. http://dx.doi.org/10.4159/harvard.9780674420106

Nunan, D. (1991). Language teaching methodology: A textbook for teachers. Hemel Hempstead: Prentice Hall International.

Oliver, R. (2002). The patterns of negotiation for meaning in child interactions. The Modern Language Journal, 86(1), 97-111. http://dx.doi.org/10.1111/1540-4781.00138

Otienoh, R. O. (2015). Implementation of Pair Work and Group Work for Creation of Interaction Opportunities for Learners in Large Classes: The Viability of the Two Strategies. Journal of Education and Practice, 6(10), 171-179.

Panova, I., \& Lyster, R. (2002). Patterns of corrective feedback and uptake in an adult ESL classroom. Tesol Quarterly, 36(4), 573-595. http://dx.doi.org/10.2307/3588241

Rahman, M. S. (2015). The contribution made by qualitative research to TESOL. International Journal of English Language Teaching, 3(2), 1-14.

Roberts, R. (2012). Drilling-based activities: Preparation light, student generated ways to build fluency. What's not to like? Retrieved from https://elt-resourceful.com/2012/07/17/drilling-based-activities-preparation-light-student-generated-ways-to -build-fluency-whats-not-to-like/

Rodgers, T. S. (2014). Approaches and methods in language teaching. Cambridge: Cambridge University Press. 
Salam, N. H. A., \& Shahrill, M. (2014). Examining classroom interactions in secondary mathematics classrooms in Brunei Darussalam. Asian Social Science, 10(11), 92-103. http://dx.doi.org/10.5539/ass.v10n11p92

Scrivener, J. (2011). Learning teaching: The essential guide to English language teaching (3rd ed.). Oxford: Macmillan Education.

Scott, P. H., Mortimer, E. F., \& Aguiar, O. G. (2006). The tension between authoritative and dialogic discourse: A fundamental characteristic of meaning making interactions in high school science lessons. Science Education, 90(4), 605-631. http://dx.doi.org/10.1002/sce.20131

Seedhouse, P. (2004). The interactional architecture of the language classroom: A conversation analysis perspective. Oxford: Blackwell Publishing.

Seedhouse, P. (1996). Classroom interaction: possibilities and impossibilities. ELT Journal, 50(1), 16-24. http://dx.doi.org/10.1093/elt/50.1.16

Sinclair, J., \& Coutland, M. (1975). Towards an analysis of discourse: the English used by the teachers and pupils. Oxford: Oxford University Press.

Stubbs, M. (1983). Discourseanalysis: The sociolinguistic analysis of natural language. Chicago: The University of Chicago Press.

Swanto, S., \& Din, W. A. (2014). Employing drilling technique in teaching English writing skills to a group of rural Malaysian students. Developing Country Studies, 4(14), 73-82.

Temmerman, M. (2009). Communicative aspects of definitions in classroom interaction: Learning to define in class for first and second language learners. Linguistics and Education, 20(2), 126-144. http://dx.doi.org/10.1016/j.linged.2009.04.003

Thornborrow, J. (2002). Power talk: language and interaction in institutional discourse. Harlow: Pearson Education Limited.

Thomson, S. B. (2011). Qualitative research: validity. JOAAG, 6(1), 77-82.

Thornbury, S. (2006). An A-Z of ELT: A dictionary of terms and concepts. Oxford: Macmillan Education.

Tice, J. (2004). Drilling 1. Retrieved from https://www.teachingenglish.org.uk/article/drilling-1

Tsui, A. B. M. (2001). 'Classroom Interaction'. In R. Carter, \& D. Nunan (Ed.), The Cambridge Guide to Teaching English to Speakers Of Other Languages (pp. 48-55). Cambridge: Cambridge University Press. $\mathrm{http}: / / \mathrm{dx}$.doi.org/10.1017/CBO9780511667206.018

Trinity College London (2016). TESOL courses - learn to teach English. Retrieved from http://www.aplusenglish.co.uk/english-and-tesol-courses/tesol-teacher-training.php

Walsh, S. (2002). Construction or obstruction: Teacher talk and learner involvement in the EFL classroom. Language Teaching Research, 6(1), 3-23. http://dx.doi.org/10.1191/13621688021r095oa

Walsh, S. (2006a). Investigating classroom discourse. London: Routledge.

Walsh, S. (2006b). Analysing classroom discourse: A variable approach. In R. Hughes (Ed.), Spoken English, TESOL and applied linguistics: Challenges for theory and practice. New York: Palgrave Macmillan. http://dx.doi.org/10.1057/9780230584587_10

Walsh, S. (2012). Conceptualising classroom interactional competence. Novitas-ROYAL (Research on Youth and Language), 6(1), 1-14. $\quad$ Retrieved from http://www.pegem.net/dosyalar/dokuman/138689-20140117105654-1.pdf

Walqui, A. (2006). Scaffolding instruction for English language learners: A conceptual framework. International Journal of Bilingual Education and Bilingualism, 9(2), 159-180. http://dx.doi.org/10.1080/13670050608668639

Waring, H. Z. (2011). Learner initiatives and learning opportunities in the language classroom. Classroom Discourse, 2(2), 201-218. http://dx.doi.org/10.1080/19463014.2011.614053

Wasik, B. A., \& Hindman, A. H. (2014). Understanding the active ingredients in an effective preschool vocabulary intervention: An exploratory study of teacher and child talk during book reading. Early Education and Development, 25(7), 1035-1056. http://dx.doi.org/10.1080/10409289.2014.896064

Wilson, R. (2015). Thinking on their feet: Assessing teachers' flexibility and responsiveness in the language classroom. In R., Wilson \& M. Polter (Eds.), Assessing Language Teachers' Professional Skills and 
Knowledge (p. 229). Cambridge: Cambridge University Press.

Woodward-Kron, R., \& Remedios, L. (2011). Classroom discourse in problem-based learning classrooms in the health sciences. Australian Review of Applied Linguistics, 30(1). http://dx.doi.org/10.2104/aral0709

Wu, B. (1998). Towards an understanding of the dynamic process of L2 classroom interaction. System, 26(4), 525-40. http://dx.doi.org/10.1016/S0346-251X(98)00036-0

\section{Appendix A}

Transcription Conventions (Based on Jefferson, 2004)

\section{[}

$=$

(.)

:

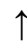

.

?

,

WORD

word

£word£

word

(word)

word-

>word $<$

.hh

(h)

((description))

$\rightarrow$
Point of overlap onset

No break or gap in speech (latched speech), or continuation of the same

turn by the same speaker even though the turn is broken up in the

transcript

Silence measured in tenths of seconds

A brief pause of about one tenth of a second

Prolongation of the immediately prior sound; the longer the colon row, the longer the prolongation

A shift into especially high pitch in the next sound

Falling intonation

Rising intonation

Slightly rising/continuing intonation

Especially loud sounds compared to the surrounding talk

Especially quiet sounds compared to the surrounding talk

Produced with "smile" voice

Emphasized segment

Transcriber's best guess of the words or speaker

A cut-off sound

Increased speed compared to the surrounding talk

Audible inbreath

Plosiveness, often associated with laughter, crying, breathlessness, etc.

Transcriber's description

Right-pointing arrow indicates a line of special interest

\section{Appendix B}

$\mathrm{T}=$ Trainee, $\mathrm{I}=$ Instructor

Excerpt 1: Interaction in Unknown (Irish) Language

1 T: Hello (.) Hello

$2 \rightarrow \mathrm{I}: \quad$ Dia dhuit (Hello) (.) Dia: dhuit (Hello)

3 T: (0.5) Dia dhuit, Dia dhuit, Dia dhuit, Dia dhuit ((whole class))

$4 \quad$ I: $\quad$ Ahh:: (0.5)

$$
\text { (Hello) (Hello) (Hello) (Hello) }
$$

5 I: $\quad$ Dia dhuit (Hello) 
$\begin{array}{llc}6 & \text { T: } & \text { Dia dhuit (Hello) } \\ 7 & \text { I: } & \text { Dia dhuit (Hello) } \\ 8 & \text { T: } & \text { Dia dhiut (Hello) } \\ 9 & \text { I: } & \text { Dia dhuit (Hello) } \\ 10 & \text { T: } & \text { Dia dhuit (Hello) }\end{array}$

(1.5) ((The instructor is writing on board))

11 I: Arís (Again) (.)

12 T: Dia gwitch ((the whole class))

13 I: Di:a...?

14 T: gwitch (1.5)

15 I: An-mhaith! (Very good!)

(.) ((The instructor is writing on board))

16 I: Dia gwitch (Hello)

17 T: hahaha (Laughter)Dia duit

18 I: Dia gwitch (Hello)

19 T: Dia duit (Hello)

20 I: Dia gwitch (Hello)

21 T: Dia duit (Hello)

Pause...

$22 \rightarrow \mathrm{I}: \quad$ Conas atá tú? (How are you?)(.)

Conas atá tú? (How are you?)=

23 I: TÁ MÉ (I’M)(.) Tá mé (I’m) (.) An-mhaith (very good) =

24 I: Le chéile (Together)

25 T: An-mhaith (very good) ((The Instructor and the whole class))

26 I: An-mhaith (Very good)

27 I: $\quad$ Is ea (Yes)

28 T: An-mhaith (Very good)

29 I: Le chéile (Together)

30 T: An-mhaith (Very good) ((The whole class))

31 I: An-mhaith (Very good)

32 T: An-mhaith (Very good) ((The whole class))

33 I: $\quad$ Go dona (Bad)

34 T: $£$ An-mhaith $£$ (Very good)(0.5) ((The whole class))

35 I: umm

36 I: Arís (Again)

37 T: An-mhaith (Very good) ((The whole class))

38 I: An-mhaith (Very good)(0.9) umm umm

39 I: go? maith. (Well)

40 T: go maith (well) ((The whole class))

41 I: go maith (well)

42 T: go maith (well) ((The whole classs))

43 I: $\quad>$ go maith $<$ (well) 


$$
\begin{array}{llll}
44 & \text { T: } & >\text { go maith }<(\text { well })((\text { The whole class })) \\
45 & \text { I: } & >\text { go maith }<(\text { well })((\text { The whole class })) \\
46 & \text { T: } & >\text { go maith }<(\text { well })((\text { The whole class })) \\
& & \text { Pause } \ldots(10 \mathrm{sec})
\end{array}
$$

47 I: $\quad$ Go dona $(\mathrm{Bad})$

48 T: $\quad$ Go dona (Bad) ((The whole class))

49 I: $\quad$ Go dona (Bad)

50 T: $\quad$ Go dona (Bad) ((The whole class))

51 I: $\quad$ Is ea (yes)

52 T: Go dona (Bad)

53 I: An-mhaith (Very good) (0.5)

54 I: An-mhaith (Very good) umm umm umm

55 I: Mohammed ((the name of a trainee)), Conas atá tú? (How are you?)

Conas atá tú? (How are you?)

56 Mohammed: Conas atá tú? (How are you?)

57 I: Conas atá tú? (How are you?)(.) Tá mé $\uparrow$ An-mhaith (I'm very good)

58 Mohammed: Tá mé An-mhaith (I'm very good)(1.7)

$59 \rightarrow \mathrm{I}: \quad$ Is ea (yes)

(1.5) Ní:: hea (no)

60 T: Ní hea (no) ((The whole class))

((The instructor is writing on board))

61 I: Go dona (Bad), Go dona (Bad)

63 T: Ní hea (no)

64 I: Ní? hea (no)

65 I: $\quad$ Go dona (Bad)

66 T: Ní hea (no) ((The whole class))

67 I: Go dona (Bad)

68 T: Yes

69 I: $\quad$ Is ea (yes)

Pause..... (The instructor is writing on board)

70 I: Le chéile (Together), Is ea (yes) ((The instructor and the whole Class))

Pause...

71 I: Nina, Conas atá tú? (How are you?)

Pause.......

72 I: An-mhaith (Very good)

73 I: Le chéile (Together), An-mhaith (Very good)= Le chéile (Together), An-mhaith (Very good)

74 T: An-mhaith (Very good) ((The whole class))

75 I: Ha uh, Nick Nick, Conas atá tú? (How are you?) 


\section{Excerpt 2: Interaction in Known (English) Language}

1 I: Tina (.) do you have any experience?

2 Tina: No

3 I: Ok (.) so (.) how did you feel in the situation?

4 Tina: um maybe debreath (.) little bit nervous. Cause? Just. came in

5 to say what is....

6 I: Right, Ok.

7 Tina: But sort of decorative, what you test bit more...

$8 \quad$ May be great doing mistake....

9 I: Right, Ok.

10 Do you like working like in pairs, groups, etc.?

11 Tina: Yea

12 I: what kind of like reasons to have (Placed) =

$13 \quad$ working in pairs and groups? (.)

14 Tina: (0.9) some idea.

15 I: Yea exactly peer learning that kind of idea $()=$.

16 creating like a learning space between themselves;

$17=$ Cause they don't know the same thing. =

18 So they can obviously help each other.

19 I: Why is that Important? (.) why is not like just (1.10)

$20 \quad \mathrm{~T}: \quad \ldots . . .^{\circ}$ constantly participating ${ }^{\circ}$

21 I: $\quad$ Yea, it's a kind of common involvement of $=$

22 learning with each other.

$23 \rightarrow \mathrm{T}: \quad{ }^{\circ}$ At the very beginning... ${ }^{\circ}=$

${ }^{\circ}$ we were vandalising each other $^{\circ}$

$£$ I'm not feeling well $£$

26 Ha ha ha ha (Laughter)

27 I: Yea? Exactly you can give that a little bit $()=$.

28 kind of doing your own speed.

$29 \quad(1.5)$

30 I: What's about the fact that like in the real world,

31 That always teachers beside the students (.) Do they need to= develop their skills?

Would you say that the approach you felt in the classroom?

Teacher-centred or quite student-centred?

35 T: $\quad$ Student-centred ((The whole class))

36 I: So (.)that's the first thing we try to establish is that the lesson you will be teaching (.) although you are going to (.) in many ways .... You are the persons who are learning because $=$ Your (.) you know (.) you are doing a training course. $=$ The irony is that you are gonna have to make your lessons studentcentred $=$ So (.) yea (.) that will be (.) We are gonna help you 
42 to do that we will give you helps and guidance and so. And you

43 know that and I know that tutor, right so, you know that

$44 \quad$ Righta (.)

45 T: Hahahaha (Laughter)

46 I: Uh! Ok? Uhh uhh (.) let's see=

47 I: Has anyone learned a language?:: But Not English=

48 maybe, learned another language (.) like school or something?

49 T: $\quad$ Yea

50 I: Yea (.) OK.

51 I: Sonny (.) the next question. What differences were this=

52 classroom that we have set up here and your past-experience=

$53 \quad$ also as a language student?

54 Sonny: It's lot more move around

55 I: $\quad$ Ok.

$56 \rightarrow \mathrm{T}: \quad$ also kind of more fun

57 I: Right

58 I: Do you know how many pupils you will be teaching? Did Boby ever

59 mention?

60 T: $\quad$ Twelve

61 I: $\quad$ Yea (.) maximum twelve.

62 I: If you are teaching the higher level: umm with Boby (.) you get

63 twelve everyday

\section{Copyrights}

Copyright for this article is retained by the author(s), with first publication rights granted to the journal.

This is an open-access article distributed under the terms and conditions of the Creative Commons Attribution license (http://creativecommons.org/licenses/by/4.0/). 